\title{
PAUL WESTHEIM
}

(1886-1963)

En la ciudad de Berlin de donde era originario, falleció el 21 de diciembre de 1963, Paul Westheim, eminente historiador del arte quien, por sus trabajos, gozaba de merecida fama, tanto en Europa como en América.

Paul Westheim llegó a México en 1941 en días difíciles para él y en México encontró una segunda patria, a la que entregó generosamente la madurez de su intelecto. Discípulo de Wöelfflin y sobre todo de Worringer, las ideas estéticas de estos maestros le sirvieron de punto de partida para entender primero y explicar después, el arte antiguo de México, que con el tiempo vino a ser la gran pasión que abrazó su vida y le dio sentido. En efecto, ya en forma de libros, de conferencias o ensayos periodísticos, Paul Westheim dedicó la parte más importante de su obra, al estudio del arte prehispánico mexicano en sus diversas manifestaciones. La bibliografía que deja al respecto es de obligada consulta para todo trabajo que quiera abordarse sobre ese tema. Los estudios sobre el arte prehispánico han perdido en Paul Westheim, a un fecundo y original investigador, pero en todo caso queda presente su obra como valioso testimonio de su labor.

A continuación señalamos los libros que Westheim dedicó al arte mexicano: Arte antiguo de México (1950). La Calavera (1953). La escultura del México antiguo (1956). Ideas fundamentales del arte prehispánico en México (1957). La cerámica del México antiguo. Fenómeno artistico (1962).

El Instituto de Investigaciones Estéticas, lamenta la muerte del distinguido historiador y crítico de arte.

X.M. 